\title{
Investigating the Effectiveness of South African Legal Framework for Civil Liability for Nuclear Damage at National Nuclear Regulator
}

\author{
Thabiso Pie \\ Management College of South Africa, 26 Samora Machel Street, Durban 4001, South Africa
}

Received May 23, 2021; Revised July 1, 2021; Accepted July 25, 2021

\section{Cite This Paper in the following Citation Styles}

(a): [1] Thabiso Pie, "Investigating the Effectiveness of South African Legal Framework for Civil Liability for Nuclear Damage at National Nuclear Regulator," Universal Journal of Management, Vol. 9, No. 4 pp. 113 - 127, 2021. DOI: 10.13189/ujm.2021.090402.

(b): Thabiso Pie (2021). Investigating the Effectiveness of South African Legal Framework for Civil Liability for Nuclear Damage at National Nuclear Regulator. Universal Journal of Management, 9(4), 113 - 127. DOI: 10.13189/ujm.2021.090402.

Copyright $\odot 2021$ by authors, all rights reserved. Authors agree that this article remains permanently open access under the terms of the Creative Commons Attribution License 4.0 International License

\begin{abstract}
Since the promulgation of the National Nuclear Regulator Act, 1999 (Act No. 47 of 1999) and the 2004 Financial Security Regulations, the impact of the framework for civil liability for nuclear damage has not been evaluated. This research investigated the effectiveness of the South African Legal Framework for Civil Liability for Nuclear Damage at the National Nuclear Regulator (NNR). The study analysed how the nuclear liability system has been implemented. Data were collected through live interviews with the NNR experts. Qualitative analysis was used to analyse how the nuclear liability system has been implemented by the NNR since its establishment in 2004, and to determine the impact of the nuclear liability system, based on cost-benefit analysis. The key findings of the research revealed that there is an alignment between the current nuclear liability system and the international best practices. Furthermore, the research has shown that the nuclear liability system has net-benefits for the public and for the NNR; and that the current nuclear liability system is partially effective. The research study concluded that the NNR can be regarded to be less effective in its role to implement the nuclear liability system. The study has found that there are areas of improvements in the legislative framework that will ensure a fully effective nuclear liability system. One of the main recommendations towards achieving an effective nuclear liability system is the need for South Africa to accede to a nuclear liability convention, and this will also contribute towards a
\end{abstract}

common coherent liability system.

Keywords Nuclear Damage, Nuclear Liability, Nuclear Liability Convention, Socio-Economic Impact Assessment System

\section{Introduction}

'Nuclear Liability' has for many decades been an area of legal scholarship, and originates particularly from the area of tort law focusing mainly on the examination of law and accidents [1]. The development of nuclear liabilities law emanated from the requirement to compensate persons for injuries and other damages caused by nuclear accidents, by ensuring adequate financial protection against nuclear damage and guaranteed access to compensation [2].

Liability in any legal system always starts with damage and ends with compensation or reparation [3]. The South African legal framework for civil liability for nuclear damage is covered under sections 29, 30, 31, 32 and 33 of the National Nuclear Regulator Act, 1999 (Act No. 47 of 1999) (the NNR Act). The National Nuclear Regulator (NNR) is established in terms of the NNR Act and is used as a case study for this research.

The framework for civil liability for nuclear damage 
(identified as the "nuclear liability system") serves two purposes relating to both, protecting the public by ensuring the availability of funds for prompt compensation for victims of nuclear damage in the event of an accident; and promoting the development of the nuclear power sector through limiting the liability amount and channelling the liability to the operator of the nuclear facility [1], [2], [4].

The following arguments are being considered in the study:

- The improvements in the international nuclear liability law, following the occurrence of nuclear disasters are still inadequate because the limited liability amounts are insufficient, and there are no international procedural provisions to ensure harmonisation of mass tort litigations [5].

- "The costs of environmental regulations need to be weighed up against the benefits they provide and which justify those regulations in the first place." [6].

- One of the areas of law where the Fukushima nuclear accident showed a serious regulatory failure is the liability for nuclear accidents [7]. Improvements to the liability system are necessary to achieve a harmonised system [8], [1].

Since the promulgation of the NNR Act in 1999 and the Financial Security Regulations in 2004, the impacts of the legislation/regulations have not been evaluated. This research intends to determine whether the South African legislative framework for civil liability for nuclear damage is effective. This will be done by looking at how the nuclear liability system is being implemented by the NNR; analysing its net benefits, and the effects thereof.

The aim of this research study is to evaluate the effectiveness of the current legislative framework for civil liability for nuclear damage at the NNR. The research is based on a qualitative research approach and a case study methodology. The outcomes of the evaluation make recommendations on areas of improvement in the current South African framework for civil nuclear liability.

\section{Materials and Methods}

\subsection{Materials}

\subsubsection{The Origins and Purpose of the Legal Framework for Civil Liability for Nuclear Damage}

The development of nuclear liabilities law emanated from the requirement to compensate persons for injuries and other damages caused by nuclear accidents, by ensuring adequate financial protection against nuclear damage and guaranteed access to compensation [2].

Nuclear liability law is intended to ensure suitable financial protection against the consequences of ionising radiation resulting from nuclear hazards, provide basic and guaranteed access to compensation, protect nuclear industry from potentially devastating liability in case of a large-scale accident, and to establish legal framework governing jurisdiction [2].

\subsubsection{The International Nuclear Liability Regime}

The two main international third party nuclear energy liability regimes operating at present are, the 1963 Vienna Convention on Civil Liability for Nuclear Damage, and the 1960 Paris Convention on Third Party Liability in the Field of Nuclear Energy [1], [9], [10]. These conventions are based upon similar basic principles to ensure similar legal treatment of third parties and the operator [10]. Furthermore, the Convention on Supplementary Compensation (CSC) provides a framework for establishing a potential global nuclear liability regime because it is regarded as a means to enhance the existing international nuclear liability regime [11].

The nuclear liability principles are essential in setting a nuclear liability system [12].The principle of the limitation of nuclear liability in amount and time has been adopted into national legislations of many countries with different amounts and forms of cover shared between the operators and governments [13].

Table 1 below indicates the amounts of compensation available under the different conventions.

Table 1. Minimum Liability amounts for the Conventions [12].

\begin{tabular}{|c|c|c|c|}
\hline $\begin{array}{c}\text { Convention } \\
\text { Party }\end{array}$ & $\begin{array}{c}\text { Operator } \\
\text { Liability }\end{array}$ & State & $\begin{array}{c}\text { Combined } \\
\text { States }\end{array}$ \\
\hline Paris 1960 & $\begin{array}{c}\text { SDR 5 - 15 } \\
\text { million }\end{array}$ & $€ 500$ & $€ 300$ million \\
\hline $\begin{array}{c}\text { Paris 2004 and } \\
\text { Brussels }\end{array}$ & $€ 700$ million & $\begin{array}{c}\text { SDR 175 } \\
\text { million }\end{array}$ & $\begin{array}{c}\text { SDR 300 } \\
\text { million }\end{array}$ \\
\hline $\begin{array}{c}\text { Brussels Supp. } \\
1963\end{array}$ & \$ million & $\begin{array}{c}\text { SDR 300 } \\
\text { million }\end{array}$ & \\
\hline Vienna 1963 & & & $\begin{array}{c}\text { SDR 300 } \\
\text { million }\end{array}$ \\
\hline Vienna 1997 & SDC & &
\end{tabular}

From Table 1 above, the CSC and Brussels Supp. 1963, requires a minimum liability amount of SDR 300 million. The Vienna 1997 requires a minimum liability amount of SDR 300 million to be covered by the state, and SDR 150 million to be covered by the operator.

\subsubsection{The South African Legal Framework of Civil Liability for Nuclear Damage}

The foundation of the current framework regulating nuclear safety in South Africa is the National Nuclear Regulator Act, 1999 (Act No. 47 of 1999), which is drawn from Article 7 of the Convention on Nuclear Safety [2].

The NNR Act provides for the NNR (as an authority on nuclear safety matters) to make recommendations to Minister of Energy on the financial security by holder of nuclear licence. The Minister must, by notice in the 
Gazette, promulgate regulations on financial security [2]. The South African civil liability for nuclear damage is covered under sections $29,30,31,32$ and 33 of the NNR Act; and the 2004 Financial Security Regulations (in Government Notice R581 in Government Gazette 26327 of 7 May 2004).

\subsubsection{The Benefits of Nuclear Liability Regimes}

In 2011, Hershovitz, Cited in [14], indicated that the indirect benefits of a nuclear liability system are:

- the information generated from the cases against nuclear accident and the compensation for nuclear damage can be disclosed for benefit of the public;

- it allows the victims of the nuclear damage to get justice by claiming for compensation from the injurer;

- the victims are given an option to claim instead of acting violently against the injurer;

- the incentives created by civil liability are used to regulate hazardous activities to ensure safety.

\subsubsection{Consequences of Major Nuclear Accidents}

A nuclear disaster can have huge financial implications. This means that the compensation system used for nuclear liabilities is in form of a direct financial compensation. The operator is required to pay third parties for the losses suffered in terms of the definition of nuclear damage [15]. In 2011, Japan Centre for Economic Research (Cited in [16]) presented that the cost of compensation and decommissioning of the six Fukushima nuclear reactors range between US $\$ 520$ billion and $\$ 650$ billion. In addition, as of January 30 2015, TEPCO has paid out $¥ 4.64$ trillion (US\$38.9 billion) in compensation [17]. With 2.5 million victim claimants and a related claimed compensation between EUR 100 - 200 billion, arguably puts Fukushima to be the largest civil liability case in legal history [7].

\subsubsection{Nuclear Insurance Pools}

As the nuclear industry developed, the nuclear operator was required to make funding provision on the basis of the principle of compulsory financial security. Financial instruments such as bank guarantees, operator pooling system, or self-insurance can be used to make a provision. Private insurance market (namely, nuclear insurance pools, captive insurance companies, mutual insurance companies, financial markets and traditional insurer/reinsurer market) have, however, usually been used to cover the nuclear power stations, and other installations of the nuclear fuel cycle and nuclear transport [18], [19]. The insurance pool is defined as a group of insurance companies that participate together to insure a specific risk or class of business [19], [20]. Various options to ensure financial security to cover for nuclear power stations, and other installations of the nuclear fuel cycle and nuclear transport, include the private insurance market such as the nuclear insurance pools.
The revision of nuclear liability conventions resulting in the increase of the compensation amount, the wider definition of nuclear damage and an increase in compensation period has become a challenge to the insurance industry and the nuclear insurance pools [18], [19].

\subsubsection{Alignment of National Legislation with the International Nuclear Liability Conventions}

The principle of channelling of liability is indicated as an important feature of the international nuclear liability conventions, with the aim to protect suppliers and for the financial viability of the nuclear industry [12]. The national law sets the minimum amount of liability cover, which can increase due to inflationary adjustments and passing the responsibility to the operator through the principle of channelisation [18], [19]. In addition, the adoption of channelisation was based on the need to assure a greater protection for the public [19].

\subsubsection{Limitations of the International Nuclear Liability Conventions}

The nuclear liability conventions do not address the procedural questions, and instead the national procedural law of the contracting parties applies for bringing compensation claims. The conventions also do not address the complex problems of mass tort obligations especially in cases of trans-boundary nuclear damage, which require international co-operation, and there is therefore no harmonised approach since the jurisdiction lies exclusively with the courts of the contracting party in whose nuclear incident occurred. This could lead to diverging judgements by different courts and not adding value to the legal peace [5].

Most of general national law has an option to handle mass litigations, but the national nuclear liability laws are silent on arranging for nuclear mass tort litigations, and leaving the decisions to the time when nuclear incident occurs [5].

\subsubsection{A Rational Regulator}

The challenge of managing the balance between environmental constraints and economic impacts has been ongoing [6]. For the regulator to determine the optimal level of care/prevention, the following should be determined: (1) the cost of prevention for each risk generator, and (2) the benefit of lower levels of risk to potential victims [14]. The complementary nature of nuclear liability regime and the safety regulations aim to provide incentives for optimal level of care to prevent accidents and ensure compensations of victims in case of a nuclear accident [14].

Rational regulators will choose policies that are not optimal for impacted stakeholders due to political pressure, especially when the regulator and policymakers are biased [21], [22]. In 1976, Peltzman, Cited in [23], mentioned 
that a rational regulator would optimise the policy outcomes by responding to the needs of the industry, and obtaining political support from the interested and impacted stakeholders.

\subsubsection{Regulatory Capture}

"Regulatory Capture is the result or process by which regulation, in law or application, is consistently or repeatedly directed away from the public interest and toward the interests of the regulated industry, by the intent and action of the industry itself". Furthermore, the motives behind the decisions of the politicians can help to distinguish between regulatory capture and advancement of public interest. This mainly arises in cases where regulations are mostly needed [24].

Even though the government can use the power to coerce in order to achieve policy goals such as public safety, regulation in the main advances private interests through political institutions which use the power of coercion to create incentives which supports the interests of the industry over the broader public's interests [23].

\subsubsection{The Role of Impact Analysis Conducted by Policymakers}

The impact analysis of policies has a role to provide evidence that guides policymakers to choose effective programs to use going forward especially for developing countries. The technical capacity constraint of policymakers makes it difficult for them to compare different studies in order to incorporate evidence in their decisions, as opposed to development organisations such as non-governmental organisations [25].

\subsubsection{The Impact of Regulations on the Nuclear Industry}

The private insurance institutions are reluctant to provide full-coverage insurance for nuclear liability and indemnity of nuclear operators due to the serious economic challenge of bankruptcy to any company as a result of the catastrophic nuclear accident [26], [27]. Therefore, the liability is capped to allow for the growth of the nuclear industry.

Environmental regulations for pollution-and energy-intensive sectors, in economies transitioning towards clean energies have shown evidence of slightly reducing employment and productivity [6]. The potential impact of environmental regulations on businesses has been a concern since the development of environmental policy in the 1970s, and conventional Economists views environmental regulations as adding costs to companies and slowing down productivity [6].

Major companies favour regulations that act as barriers of entry against competitors, and enhance their profits when they are exempted from regulations applicable to new entrants [23]. Ineffective regulation has resulted into onerous licencing conditions which act as barriers of entry for new entrants into the market, and the existing major companies use their capability and resources to influence the terms of debate and lobbying to influence the policy outcomes to their advantage [28].

\subsubsection{The Impact of Nuclear Liability Law on the Public}

The public should be able to direct, control and own the development and decision-making processes of policy through their level of influence [29]. The public is given less incentive to learn about policy proposals and this limits their ability to participate actively and decide on their preferred options so that they are able to hold the politicians responsible for policy development accountable [23].

\subsubsection{The Impact of Nuclear Disasters on the Regulator}

In a few cases of industrial accidents, the regulator has been found to be responsible due to their non-performance. However, it becomes difficult to hold the regulator to account because (1) accountability diminishes with time, and undermines other regulatory attributes such as independence, expertise and efficiency; (2) the difficulty of effectively measuring the performance of the regulator [14].

\subsubsection{Nuclear Liability Regime Challenges}

One of the challenges of the international nuclear liability law is its fragmentation, which is still significant in terms of applicable conventions, liability amounts, reciprocity rules, and many other subjects [30].

The proposed increases in the compensation amounts in the revised Conventions will still not fully cover the potential costs of major nuclear accidents. Currently, the cost of Fukushima nuclear accident is more than forty times greater than TEPCO's liability limit [31]. Very few victims have been adequately compensated despite pleading themselves before nuclear operator (TEPCO) [15]. This also means that the objective of the liability regimes of ensuring adequate compensation has not been achieved.

Since the review of the international nuclear third party liability regime (namely, framework for civil liability for nuclear damage), the insurance industry has been faced with the challenge of finding funds that correspond to the new minimum liability amounts that have been set. Another challenge is whether the additional damages covered by the revised conventions provide adequate cover for existing risks, and if the private insurance is able and willing to cover such risks [31]. The challenges facing the insurance industry since the implementation of the nuclear liability regime need to be looked to see the extent to which the current South African nuclear liability system addresses them.

One of the challenges regarding the nuclear liability Conventions is that only a few countries have signed and ratified to these Conventions, especially the most recent revisions to the Conventions [1]. 
The Chernobyl accident has raised awareness of the problem of trans-boundary impacts of nuclear incidents. However, a true global nuclear liability regime with full compliance to the conventions or applicable national laws has yet to materialise [12]. The existence of the different conventions and some countries not signed to any convention does not solve the practical challenges of the trans-boundary impacts of nuclear accidents [17].

\subsubsection{Effectiveness of Nuclear Liability Conventions}

The new revisions of the international nuclear liability conventions have not been effective because of the following reasons: the countries that have ratified or acceded to the Conventions are less than the required number, and therefore these Conventions are not yet into force; and the nuclear liability regime is not harmonised throughout the European Union [18]. However, the effectiveness of the principles of the international nuclear liability conventions have been proven during the 2011 Fukushima nuclear accident, even though there are still areas for improvement [8].

\subsection{Research Methodology}

For this research, the starting point identified is the nuclear liability framework as a single case. Then the appropriate approach to the research is the case study design. The rationale for choosing a case study design is because the nuclear liability framework is being investigated as to whether it has been effective over time since its establishment in 2004. The single case chosen is the NNR, who is responsible for the implementation of the nuclear liability framework. The live interviews were conducted with the identified participants at the NNR in order to collect information on the organisational processes around the implementation of the nuclear liability framework, using questions based on the objectives of the research. The analysis of the data obtained was used to make recommendations to the improvements to the nuclear liability framework.

The qualitative approach was used in this research to explore and describe the views of the participants on the identity and the current implementation of the South African nuclear liability framework at the NNR. In order to gather this kind of data, the participants were interviewed to capture their thoughts and feelings about the how the liability framework is being implemented by the NNR. This allowed the researcher to understand the meaning behind the participants' views, understanding, and experiences in the implementation of the nuclear liability framework. A qualitative approach was therefore appropriate to capture the information presented by the participants in connection with the research questions during the interviews.

The information presented is a result of interviews held with the three participants who have experience in the field of nuclear liability. Overall, the information collected does accurately present the experiences of participants on how the nuclear liability framework has been implemented in South Africa, since its establishment. The participants also gave a clear description of the nuclear liability framework of South Africa, which is in line with the legislation. Furthermore, participant's views, experience and understanding of the impacts of nuclear liability framework were also provided through the interviews. The information collected is interpreted to be essential in addressing the research questions, which provide accurate understanding about the effectiveness of the nuclear liability framework.

In this research, the research strategy chosen is the case study. This is because the NNR is identified as the organisation of interest, which is responsible for the implementation of the nuclear liability system. Therefore, an in-depth investigation of the effectiveness of the nuclear liability system can be conducted with the NNR as the case.

The target population was NNR employees. The NNR employees who are experts in the subject of nuclear liabilities or are responsible for the implementation of the legal framework for nuclear liability and compliance thereof were identified.

The sample size was 3 NNR participants. Qualitative methodology was used because the NNR has a few experts on nuclear liability.

A non-probability approach to sampling was adopted. The rationale for choosing the non-probability sampling is because most accurate the data on the implementation of the nuclear liability system can be obtained from interviewing the identified NNR participants. In particular, purposive sampling (namely, Judgment sampling) was used because the NNR experts in the subject who can provide in-depth information regarding the research questions were selected.

It is also worth noting that the use of non-probability sampling is prone to sampling bias. Even though non-probability sampling is inherently prone to sampling bias, this sampling technique was used with the understanding that the researcher understands the subject matter and that the selected participants are only a few experts in the subject of nuclear liabilities, who have experience in the implementation of the nuclear liability system.

For the research questions to be addressed, the required data needs to be obtained from the identified participants at the NNR. This data is regarded as original and obtained directly from the participants for the first time since the establishment of the nuclear liability framework. For this qualitative research, the most appropriate data collection method is the interviews.

The rationale for using the semi-structured open-ended interviews as the method of collecting primary data is because they allow the researcher to gather more accurate 
answers and data through in-depth one-on-one discussions with the participants. The semi-structured interviews provide information for the research based on the interpretation by the researcher, using the pre-set open-ended questions. The interviews allow for uncovering of the underlying reasons and motivations of the information obtained through in-depth discussions. The interviews also allow more accurate and realistic responses to be provided by the participants based on their thoughts, ideas, and perceptions. Even though the interviews will be time consuming, they are more economical as opposed to other methods.

In this qualitative research, the participants were interviewed through a face-to-face experience/interaction. In this study, it was expected that the researcher would be biased, and the researcher should be conscious of the bias and minimise it through a good attitude, objective views, and understanding of the discussions in order for one to provide a correct perspective about the information.

The interview questions addressed the following main areas:

- The current identity of the South African nuclear liability framework.

- Identifying the net benefits of the South African nuclear liability framework.

- The information on the effectiveness of the current South African legal framework for civil liability for nuclear damage at the NNR.

- How the implementation of the South African legal framework for civil liability for nuclear damage by the NNR can be improved.

For this research, thematic analysis was used to analyse the qualitative data collected through the interviews. The rationale for choosing the thematic analysis is because the textual data obtained can be categorised into themes, and interpreted by identifying commonalities and explanations using the methodologies chosen.

Therefore, the participants' perspectives and understanding that was provided during interviews was categorized into coded information based on themes developed from the interview questions. The coded information was analysed appropriate thematic analysis methodology, in order to assess the effectiveness of the legal framework for nuclear liability in South Africa.

The performance of a regulatory policy can be measured by evaluating both the (i) substantive outcomes of the regulations and (ii) any relevant process outcomes (namely, regulatory policy). The following criteria can be used when analysing the choice between different regulatory options: (i) Impact/Effectiveness (changes in the problem or other outcomes of concern); (ii) Cost-effectiveness (costs for a given level of impact); and (iii) Net Benefits (all beneficial impacts minus all costly impacts). Therefore, a regulatory impact analysis of an existing legislation was conducted [32].

The three types of measures or indicators are regulatory administration, behavioural compliance, and outcome performance [32]. One of the limitations of net-benefits approach is that it may not always be possible to quantify and monetise all benefits and costs [32]. Therefore, impact/effectiveness criterion was used to measure the performance of the nuclear liability system. The indicators measured (namely, regulatory administration, behavioural compliance, and outcome performance) was analysed, using the description of the costs and benefits to determine the net-benefits.

During the interviews conducted under this research, the bias was minimised and the validity increased so that the information obtained is an accurate reflection of the responses to the research questions. This was assured by the positive general behaviour of the researcher when interacting with the participant and analysing interview data.

The data collected from the participants was checked for trustworthiness. A good relationship was established with the participants to allow for an open and honest engagement.

Therefore, the effectiveness of the nuclear liability framework in South Africa was assessed, through an in-depth contextual analysis and interpretation of information collected through interviews, using the NNR as the identified case. The NNR, which is responsible for the implementation of the aforementioned framework, is the focus for this case study. The case study design was more appropriate for this research.

\section{Results}

The evaluation of the policy/legislation involves identification of options for addressing the problem (Department of Planning, Monitoring, and Evaluation, 2015:7). The following options have been identified based on the current existing legislation on nuclear liability and the work that is done by the NNR towards improving the nuclear liability system of South Africa, as presented by the participants (Figure 1.).

The criteria, which was used when analysing the choice between different regulatory options is the Impact/Effectiveness (changes in the problem or other outcomes of concern). The three themes of the thematic analysis, which were used to analyse the data through the description of the costs and benefits to determine the net-benefits are (i) regulatory administration, (ii) behavioural compliance, and (iii) outcome performance. 


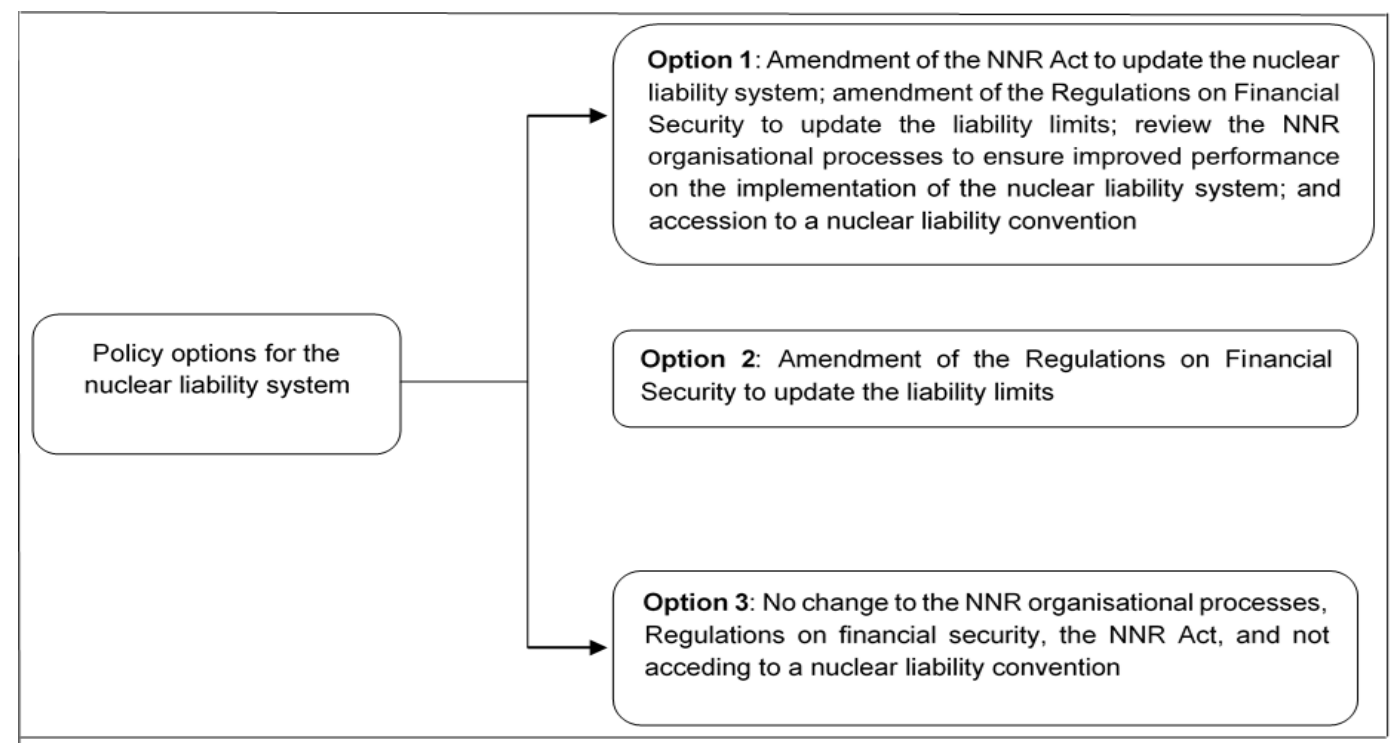

Source: ([33])

Figure 1. Policy options for the nuclear liability system

Table 2. Benefits

\begin{tabular}{|c|c|c|}
\hline $\begin{array}{c}\text { Affected } \\
\text { stakeholders }\end{array}$ & The main benefits & $\begin{array}{c}\text { Applicable Policy } \\
\text { options }\end{array}$ \\
\hline \multicolumn{3}{|c|}{ Regulatory administration } \\
\hline \multirow[b]{2}{*}{ NNR } & $\begin{array}{c}\text { The compensation scheme is a legislated process. This forms the basis of the nuclear liability } \\
\text { requirements }\end{array}$ & $\begin{array}{l}\text { Option 1; Option 2; } \\
\text { Option } 3\end{array}$ \\
\hline & $\begin{array}{l}\text { The IMS streamlines all the NNR business systems (include liability processes), it ensures } \\
\text { transparency, continuity, and consistent application of the NNR requirements (including liability), } \\
\text { and allows for documentation of inspections. The IMS ensures that the nuclear liability system is } \\
\text { implemented. }\end{array}$ & $\begin{array}{l}\text { Option 1; Option 2; } \\
\quad \text { Option } 3\end{array}$ \\
\hline $\begin{array}{l}\text { Nuclear } \\
\text { Operators }\end{array}$ & \multicolumn{2}{|l|}{ Not identified } \\
\hline $\begin{array}{l}\text { Insurance } \\
\text { pools }\end{array}$ & \multicolumn{2}{|l|}{ Not identified } \\
\hline Public & No burden of proof on the public to claim for the compensation & $\begin{array}{l}\text { Option 1; Option 2; } \\
\text { Option } 3\end{array}$ \\
\hline Government & & \\
\hline \multicolumn{3}{|c|}{ Not identified } \\
\hline NNR & $\begin{array}{l}\text { The NNR does train its experts on the implementation of the NNR Act, including the liability } \\
\text { requirements. However, the training on the overall liability requirements are made as part of the } \\
\text { NNR induction programme. }\end{array}$ & $\begin{array}{l}\text { Option 1; Option 2; } \\
\text { Option } 3\end{array}$ \\
\hline \multirow{2}{*}{$\begin{array}{l}\text { Nuclear } \\
\text { Operators }\end{array}$} & $\begin{array}{l}\text { There is certainty in the liability cover. In case of a recourse the operator has certainty in the } \\
\text { liability, and therefore ensures the viability of the business. }\end{array}$ & Option 1; Option 2 \\
\hline & $\begin{array}{l}\text { When the nuclear liability system is in line with international developments, it provides certainty } \\
\text { to countries and companies that participate in the nuclear sector as suppliers and service providers. }\end{array}$ & Option 1 \\
\hline $\begin{array}{c}\text { Insurance } \\
\text { pools }\end{array}$ & $\begin{array}{l}\text { Annual meetings are held with the insurance pools. These meetings allow for continuous } \\
\text { engagement on the issues related to the implementation of the nuclear liability requirements. }\end{array}$ & $\begin{array}{l}\text { Option 1; Option 2; } \\
\text { Option } 3\end{array}$ \\
\hline \multirow{2}{*}{ Public } & $\begin{array}{l}\text { There is an insurance in place to cover for a nuclear accident, and the public will be compensated } \\
\text { in case of a nuclear accident. }\end{array}$ & $\begin{array}{l}\text { Option 1; Option 2; } \\
\text { Option } 3\end{array}$ \\
\hline & $\begin{array}{l}\text { Through the public consultation process civil groups are given the platform to arise their concerns, } \\
\text { which are regarded to be of benefit to the public. }\end{array}$ & $\begin{array}{l}\text { Option 1; Option 2; } \\
\text { Option } 3\end{array}$ \\
\hline \multirow{2}{*}{\multicolumn{3}{|c|}{$\begin{array}{l}\text { Not identified } \\
\text { Outcome performance }\end{array}$}} \\
\hline & & \\
\hline NNR & There are no significant administrative burdens. & $\begin{array}{l}\text { Option 1; Option 2; } \\
\text { Option } 3\end{array}$ \\
\hline $\begin{array}{c}\text { Nuclear } \\
\text { Operators }\end{array}$ & $\begin{array}{l}\text { There is certainty in the liability cover. However, in case of a recourse there is uncertainty on what } \\
\text { the operator will be required to pay, and therefore impacts negatively on the nuclear industry. }\end{array}$ & Option 2; Option 3 \\
\hline $\begin{array}{c}\text { Insurance } \\
\text { pools }\end{array}$ & Not identified & \\
\hline Public & Not identified & \\
\hline Government & $\begin{array}{l}\text { An established nuclear liability system that is adequate and improved in line with international } \\
\text { best practices (for example, broader scope for nuclear damage). }\end{array}$ & $\begin{array}{l}\text { Option 1; Option 2; } \\
\text { Option } 3\end{array}$ \\
\hline
\end{tabular}


Table 3. Costs

\begin{tabular}{|c|c|c|}
\hline $\begin{array}{c}\text { Affected } \\
\text { stakeholders }\end{array}$ & The main costs & $\begin{array}{l}\text { Applicable Policy } \\
\text { options }\end{array}$ \\
\hline \multicolumn{3}{|c|}{ Regulatory administration } \\
\hline NNR & The direct administrative costs have not been quantified. & $\begin{array}{l}\text { Option } 1 \text {; Option 2; } \\
\text { Option } 3\end{array}$ \\
\hline Nuclear Operators & Not identified & \\
\hline Insurance pools & Not identified & \\
\hline Public & $\begin{array}{l}\text { In the case where the nuclear accident occurs and the insured operator liability has been } \\
\text { exceeded, then public funds will be made available in form of parliamentary } \\
\text { appropriations. }\end{array}$ & $\begin{array}{l}\text { Option 1; Option 2; } \\
\quad \text { Option } 3\end{array}$ \\
\hline Government & $\begin{array}{l}\text { The nuclear liability system takes into account the cost in excess to the operator liability, } \\
\text { which will be covered by public funds through Parliamentary appropriations }\end{array}$ & $\begin{array}{l}\text { Option 1; Option 2; } \\
\text { Option } 3\end{array}$ \\
\hline \multicolumn{3}{|c|}{ Behavioural compliance } \\
\hline NNR & $\begin{array}{l}\text { There are no significant cost implications on the NNR in the implementation of the } \\
\text { nuclear liability system. The costs for implementation of the nuclear liability system are } \\
\text { covered under the normal operational budget. }\end{array}$ & $\begin{array}{l}\text { Option } 1 \text {; Option 2; } \\
\text { Option } 3\end{array}$ \\
\hline Nuclear Operators & $\begin{array}{l}\text { The cost is on the operator in that they have to take a monetary policy as required by the } \\
\text { nuclear liability system. This involves the payment of premiums to the insurance pools for } \\
\text { the cover. }\end{array}$ & $\begin{array}{l}\text { Option 1; Option 2; } \\
\quad \text { Option } 3\end{array}$ \\
\hline Insurance pools & The cost on insurance pool to determine the premiums. & $\begin{array}{l}\text { Option 1; Option 2; } \\
\text { Option } 3\end{array}$ \\
\hline Public & Not identified & \\
\hline Government & Not identified & \\
\hline \multicolumn{3}{|c|}{ Outcome performance } \\
\hline NNR & $\begin{array}{l}\text { A site-specific research was once conducted by the NNR, and it was identified that this is } \\
\text { an inter-disciplinary and costly exercise, and that data is not readily available. Hence a } \\
\text { benchmarking exercise was conducted }\end{array}$ & $\begin{array}{l}\text { Option 1; Option 2; } \\
\quad \text { Option } 3\end{array}$ \\
\hline Nuclear Operators & $\begin{array}{l}\text { The increased liability amounts are based on realistic amounts on the adequate operator } \\
\text { liability }\end{array}$ & Option 2; Option 3 \\
\hline Insurance pools & Not identified & \\
\hline Public & Not identified & \\
\hline Government & Not identified & \\
\hline
\end{tabular}

Table 2 indicates the benefits of the nuclear liability system for the identified stakeholders, which have been categorised into themes; and the applicable policy options.

Table 3 indicates the costs of the nuclear liability system for the identified stakeholders, which have been categorised into themes; and the applicable policy options.

\section{Discussion}

\subsection{Findings from the Literature Review}

The following findings have been identified from literature review (section 2.1 Materials):

\subsubsection{National Nuclear Regulator}

- The insurance industry and the nuclear insurance pools do have a challenge with providing coverage based on the wider definition of nuclear damage and an increase in compensation period, which are prescribed in the articles of the some of the relevant nuclear liability conventions. In addition, when acceding to CSC some of the challenges that can be expected include how to define nuclear damage and the period of exclusion. Therefore, the definition of nuclear damage is pivotal to determining the extent of insurance cover, and the magnitude of damage that can be caused by nuclear disasters and period of exclusion do influence the extent of cover provided by the insurance. This challenge can limit the objective of the nuclear liability system to a certain extend.

- The different nuclear liability systems for various countries do lead to a fragmented international nuclear liability regime. The fragmented systems can be due to the uniqueness of the national legislations of the different countries. Therefore, there is a need to harmonise the nuclear liability systems of the different countries, and one of the ways of doing so is through acceding to one of the relevant nuclear liability conventions.

The existence of different nuclear liability Conventions and a number of countries not being Contracting Parties has resulted in the challenges in dealing with trans-boundary impacts of nuclear accidents. This means that in case of a nuclear accident, the different Conventions leave the issues of claims to the courts of the country where the accident 
took place. Therefore, the different courts will make different judgements regarding the claims made by other countries which have been impacted by the accident. This could limit the objective of the nuclear liability system in that the victims from other countries may not be adequately compensated.

- The private insurance institutions have been reluctant to provide full-coverage insurance for nuclear liability and indemnity of nuclear operators because of serious economic challenge of bankruptcy to any company due to a nuclear accident. Therefore, the nuclear accident has a potential to run organisation into bankruptcy, including the insurance companies. In order to make the nuclear industry viable, the liability of the operator is capped for some nuclear liability Conventions.

- The structural design of the regulator for advancing public welfare (for example, information disclosure) can be used to blame the regulator as one of the causes of a nuclear disaster. It is therefore important that the regulator has capacity and processes in place to ensure that the nuclear liability system is implemented in a transparent manner. As a result, the public will be assured that they will be compensated in case of a nuclear accident, and that the impacted stakeholders will be given a platform to raise their issues on the policy decisions.

- It can be difficult to hold the regulator accountable during an accident because of the diminishing of accountability with time. This can lead to a perception that the regulator is not independent, has no expertise and is inefficient. Therefore, this could make it difficult to measure its performance. Furthermore, the roles and responsibilities of the regulator during a disaster need to be articulated so that they it is held accountable for its performance.

\subsubsection{Operator}

- The regulations can act as a barrier of entry for new companies that enter the nuclear industry, in favour of major companies, which are already within the industry. This can occur especially if the required minimum nuclear liability amounts are not affordable for the small companies. Therefore, even though the objective of the nuclear liability system is to ensure adequate compensation, the nuclear industry may be negatively affected and may be less competitive.

\subsubsection{Public}

- There is a challenge regarding the public being able to direct, control and own the development and decision-making processes of policy. The means the public is unable to influence the policy outcomes. As a result, the objectives of the nuclear liability system may not be achieved because the interests of the public may have not been expressed accurately in the policy. Therefore, as part of the public consultation process, the public needs to be educated about nuclear liability system.

\subsubsection{Government}

- The challenge of having major companies with capability and resources in an industry can influencing the terms of debate, and lobbying to have policy outcomes to their advantage. This could result in a policy that does not ensure the safety of public and environment. Therefore, in such a case the objective of a nuclear liability system of ensuring safety and adequate compensation of victims may not be achieved.

- The challenge of policymakers not having technical capacity to do comparative studies on different policy options in order to incorporate the evidence in their decisions. Instead, the development organisations such as non-governmental organisations may have the technical capacity. This could lead to the policy outcomes that favour other interests that do not optimise the objectives of the nuclear liability system (namely, ensuring adequate compensation of victims versus the viability of the nuclear industry).

- The claims process for the nuclear liability system for South Africa is not clearly outlined, and this can be a challenge. The Conventions normally leave this issue to be addressed through the national legislation. In such a case the processes are only determined during the time of the nuclear accident. This could lead to a number of uncertainties, mainly to the public because they would not be assured that they will be compensated in case of an accident.

- The lack of a harmonised approach to claims processes can be a challenge because it can result in diverging judgements by different courts and does not add value to the legal peace. Therefore, other victims may not be adequately compensated, especially if they are from another country where the accident has caused a trans-boundary impact. This can hinder the nuclear liability system in achieving its objective optimally.

\subsection{Findings from the Primary Research}

\subsubsection{The Identity and the Current South African Framework for Civil Liability for Nuclear Damage}

The nuclear liability system is based on the international nuclear liability conventions with specific principles. The definition of nuclear damage is central to determining the scope of insurance cover. In terms of the NNR Act, the NNR implements the nuclear liability system. The regulations set the required minimum liability amounts for the three categories of nuclear facilities.

The NNR has the transparent processes to regulate operators on the requirements of the nuclear liability 
system, and making recommendations to the Minister for promulgation. The NNR ensures that in case of a nuclear accident, the victims can claim for compensation, and additional funds can be made through parliamentary appropriations.

Currently the challenge with the claims period is that the insurance only provides cover to 10 years instead of 30 years as required by the NNR Act. Another challenge identified is the uncertainty that can be as a result of requiring the operators to cover excess claims through recourse in line with the NNR Act.

\subsubsection{The Net Benefits of the South African Framework for Civil Liability for Nuclear Damage}

\section{(i). Net-benefits (effectiveness) on the NNR}

The nuclear liability system is a legislated process that is implemented by the NNR in a rational and transparent manner. The challenges with the claims period, the extent of insurance cover, the fragmented global nuclear liability regime, and the roles and responsibilities of the NNR within the nuclear liability system, still need to be addressed. Some of the challenges are being addressed through strengthening of legislation. The implementation of the nuclear liability system does not have significant cost implications, unless a dedicated competent unit is established. However, political pressure may influence its decisions.

Under option 1 the nuclear liability system is effective because of an improved nuclear liability system that will achieve its objectives optimally; partially effective for option 2 because the legislative framework will need further improvement; and less effective under option 3 because the current challenges are not addressed.

\section{(ii). Net-benefits (effectiveness) on the government:}

The nuclear liability system is of benefit to government because it ensures that the victims get financial protection and justice by claiming for compensation; ensures viability of the nuclear industry; and to hold the NNR accountable. The establishment/review of the nuclear liability system has no significant cost implications. However, there is a need to have technical capacity for policymakers. One of the main issues to be addressed by government include the need to outline the claims process/procedure.

The nuclear liability system under option 1 can become effective because whilst it provides financial protection and justice by claiming for compensation, it does require further improvements. These improvements will ensure that there is clarity on how the NNR would be held liable in the implementation of nuclear liability system; there is capacity for policymakers (that is, technical capability) to be able to give policy direction; and the claims process/procedure is defined. Under option 2 and 3, the nuclear liability system does not show effectiveness because even though it provides financial protection and justice by claiming for compensation, it does not address challenges of holding the NNR liable for implementation of the nuclear liability system, and capacitating policymakers.

\section{(iii). Net-benefits (effectiveness) on the public}

The nuclear liability system does benefit the public because it provides financial protection, and the victims can be assured to get justice by claiming against nuclear damage suffered. The public has no burden of proof in order to claim for the compensation

The nuclear liability system does show effectiveness under option 1 because there are no identified costs and the public is assured to claim for compensation in case of a nuclear accident, even though public funds through Parliamentary appropriations may be used. Option 2 and 3 does show partial effectiveness because the compensation amounts in this case may be insufficient and the definition of nuclear damage may not be broad enough. Furthermore, public may not have an influence on the decisions made regarding the nuclear liability system. Therefore, there is a need to ensure that the public is given more incentive to learn about policy proposals to allow for active participation in deciding on the preferred policy options, so that they are able to hold the policymakers accountable.

\section{(iv). Net-benefits (effectiveness) on the operator}

The nuclear liability system does benefit operators because it provides certainty in the liability/insurance cover; allows for participation of suppliers and service providers in the nuclear industry, and assures financial viability of the nuclear industry. The identified costs are payment of premiums for the insurance, and these costs can be increased significantly if the definition of nuclear damage becomes broader. In such a case, some operators may be impacted negatively and can act as a barrier of entry for new businesses.

Therefore, under option 1, the nuclear liability system does show effectiveness because even though the increased liability amounts could negatively affect the nuclear industry and the regulations could act as barriers of entry for new businesses, it does however, provide certainty of the established business, protects the suppliers within the nuclear industry, and is an incentive for nuclear safety. The proposed increases to the liability amounts could be within reasonable means to the operator. Option 2 does not show effectiveness because although it also provides certainty in business and is an incentive for nuclear safety, it does not ensure channelisation, impacts negatively on the nuclear industry, and acts as barriers of entry for new businesses. Option 3 does not show effectiveness because despite providing certainty in business and being an incentive for nuclear safety, it does not channelisation, acts as barriers of entry for new businesses; and the set liability amounts in the regulations could be insufficient, and hence not supporting the 
intended purpose of the nuclear liability system.

\section{(v). Net-benefits (effectiveness) on the insurance pool}

The private insurance institutions have been reluctant to provide full-coverage insurance for nuclear liability and indemnity of nuclear operators because of serious economic challenge of bankruptcy to any company due to a nuclear accident. Under option 1, 2, and 3, the net-benefits have not been identified for the insurance pools.

\subsubsection{The Effectiveness of the Current South African Framework for Civil Liability for Nuclear Damage at the National Nuclear Regulator}

The assessment of the effectiveness of the nuclear liability system for the three policy options is determined in the table 4.

The table 4 indicates that option 1 is effective for all the stakeholders, option 2 is partially effective, and option 3 is less effective. Therefore, the current nuclear liability system is less effective and requires further improvements as proposed under option1 to ensure that it becomes effective.

\section{Conclusions and Recommendations}

\subsection{Summary}

5.1.1. Description of the Identity of and the Current South African Framework for Civil Liability for Nuclear Damage

The nuclear liability system is characterised by the provisions of Chapter 4 of the NNR Act and associated regulations on financial security; and is based on the international nuclear liability conventions with specific principles.

The implementation of the nuclear liability system is through NNR processes which are transparent. The NNR does ensure that in case of a nuclear accident the victims are able to claim for compensation based on the definition of nuclear damage. The challenges of claims period and recourse on the operator still need to be addressed.

\subsubsection{The Net Benefits (Effectiveness) of the South African Framework Civil Liability for Nuclear Damage}

The assessment of net benefits was used to determine the impacts of the costs and benefits of the nuclear liability system on the identified stakeholders, and the outcome shows its effectiveness.

\section{(i). Net-benefits (effectiveness) on the NNR}

Under option 1 the nuclear liability system is effective because it is legislated and it has no significant cost implications of the NNR. The challenges of the claims period; the extent of insurance cover; the fragmented global nuclear liability regime; and the roles and responsibilities of the NNR within the nuclear liability system, can be addressed through strengthening of legislation as proposed. Option 2 is partially effective because the legislative framework will need further improvement, and less effective under option 3 because the current challenges of the nuclear liability system are not addressed.

Table 4. Effectiveness for the Policy Options

\begin{tabular}{|c|c|c|c|c|c|}
\hline \multirow{2}{*}{ Policy options } & \multicolumn{5}{|c|}{ Stakeholders } \\
\cline { 2 - 6 } & NNR & Operator(s) & Public & Government & Overall effectiveness \\
\hline Option 1 & Effective & Effective & Effective & Effective & Effective \\
\hline Option 2 & Partially effective & $\begin{array}{c}\text { does not show } \\
\text { effectiveness }\end{array}$ & Partially effective & $\begin{array}{c}\text { does not show } \\
\text { effectiveness }\end{array}$ & Partially effective \\
\hline Option 3 & Less effective & $\begin{array}{c}\text { does not show } \\
\text { effectiveness }\end{array}$ & Partially effective & $\begin{array}{c}\text { does not show } \\
\text { effectiveness }\end{array}$ & Less effective \\
\hline
\end{tabular}




\section{(ii). Net-benefits (effectiveness) on the operator(s)}

The identified costs are payment of premiums for the insurance, and these costs can be increased significantly if the definition of nuclear damage becomes broader. Under option 1, the nuclear liability system does show effectiveness because even though the increased liability amounts could negatively affect the nuclear industry and the regulations could act as barriers of entry for new businesses, it does however, provide certainty of the established business, protects the suppliers within the nuclear industry, and serves an incentive for nuclear safety. The proposed increases to the liability amounts could be within reasonable means to the operator. Option 2 does not show effectiveness because although it also provides certainty in business and is an incentive for nuclear safety, it does not ensure channelisation; it impacts the nuclear industry negatively, and acts as barriers of entry for new businesses. Option 3 does not show effectiveness because despite providing certainty in business and being an incentive for nuclear safety, it does not channelisation, acts as barriers of entry for new businesses; and the set liability amounts in the regulations could be insufficient, and hence not supporting the intended purpose of the nuclear liability system.

\section{(iii). Net-benefits (effectiveness) on the public}

The nuclear liability system does show effectiveness under option 1 because there are no identified costs and the public gets financial protection and is assured to claim for compensation in case of a nuclear accident. The public has no burden of proof in order to claim for the compensation. Option 2 and 3 does show partial effectiveness because the compensation amounts in this case may be insufficient for option 3 and the definition of nuclear damage may not be broad enough for both option 2 and 3. Furthermore, public may not have an influence on the decisions made regarding the nuclear liability system. Therefore, there is a need to ensure that the public is given more incentive to learn about policy proposals to allow for active participation in deciding on the preferred policy options, so that they are able to hold the policymakers accountable.

\section{(iv). Net benefits (effectiveness) on the government}

There are no identified significant costs on government towards implementation of the nuclear liability system. The costs will be on government if the operator liability is exhausted and funds are made available through parliamentary appropriations. The nuclear liability system under option 1 is effective because whilst it provides financial protection and justice to victims, further improvements are made through legislation to ensure the following: clarify on how the NNR will be held liable in the implementation of nuclear liability system; defining the claims process/procedure. The issue of capacitating policymakers (that is, technical capability) to be able to give policy direction depends on the availability of funds. Under option 2 and 3, the nuclear liability system does not show effectiveness because even though it provides financial protection and justice by claiming for compensation, it does not address identified challenges. These challenges are as follows: holding the NNR liable for implementation of the nuclear liability system through amendment of legislation; having a limited scope of cover for nuclear damage; and the need for capacitation of policymakers.

\subsubsection{The Effectiveness of the Current South African Framework for Civil Liability for Nuclear Damage at the National Nuclear Regulator}

Based on the identified stakeholders (namely, NNR, operators, public, government, and insurance pool), the assessment of the effectiveness of the nuclear liability system for the three policy options has indicated that the current nuclear liability system (that is, option 3 ) is less effective. However, further improvements are proposed under option 2, which can make the nuclear liability system partially effective. Option 3 is the preferred option, which proposes legislative improvements, and will make the nuclear liability system effective.

\subsection{Recommendations}

The legislation on nuclear liability system needs to be improved to address the following:

- To outline the claims process/procedure for the victims who suffered nuclear damage.

- To specify the required amount for the recourse on the operator should the insured compensation amounts be exhausted.

- To clarify roles and responsibilities of the NNR within the nuclear liability system in an event of a nuclear disaster.

- To clarify on how the NNR will be held liable in the implementation of nuclear liability system.

- To revise the current required minimum liability amounts to adequate levels, whist taking into account the financial impact on the operators (for example, increase with inflationary adjustments). The increases should also take into account that they can act as a barrier of entry for new businesses, and could therefore limit the growth and competitiveness within the nuclear industry.

- To have a special independent authority with its decisions appealable to the Court of Law, and whereby controversial claims can be referred to the Courts. This will ensure that the claims submitted are expedited, in order to achieve the objective of the nuclear liability system.

The relevant stakeholders need to engage with the insurance pool to determine alternative solutions towards ensuring that the claims period is for 30 years as 
prescribed in the NNR Act instead of 10 years, and how the insurance will cover other damages indicated in the updated nuclear liability Conventions. The following alternative options can be explored: bank guarantee, operator pooling system, self-insurance, or private insurance market (namely, captive insurance companies, mutual insurance companies, financial markets and traditional insurer/reinsurer market).

Latest technology such as an online form can be used for the purposes of registration for the claims to be processed, and for verification of the information provided by the victims to avoid fraudulent claims.

There is a need for policymakers to assess their technical capability in order to effectively provide policy direction. There might be a need to have a dedicated competent unit responsible for the implementation of the nuclear liability system.

The public needs to be educated more about the nuclear liability system to empower them so that they can influence policy decisions and to hold the policymakers accountable.

South Africa needs to accede to one of the international nuclear liability Conventions to work towards having a harmonised nuclear liability regime. The CSC is recommended because of the supplementary funds for compensation for victims.

\subsection{Conclusions}

The research indicates that the current nuclear liability system of South Africa is less effective, and does make recommendations for improvements. Therefore, the objectives of the study have been achieved because of the following:

- the assessment has given the current identity of the nuclear liability system of South Africa;

- the net-benefits have been determined for the impacted stakeholders under the three policy options. (that is, (1) amendment of NNR Act and Regulations, and acceding to a nuclear liability convention; (2) updating of Regulations; or (3) no changes); and

- the current nuclear liability system has been assessed to be less effective.

The study makes recommendations for further improvements mainly though strengthening of the South African legislative framework for civil liability for nuclear damage; and the accession to an international nuclear liability convention to address the lack of common coherent global nuclear liability system.

This research does contribute to the practical understanding of the global nuclear liability regime, and its elements since its establishment from tort law. All liability regimes start with damage and end with compensation. Further research in the area of global nuclear liability regime is essential to contribute towards the harmonisation of the different nuclear liability frameworks.

The Regulatory Impact Assessment methodology has shown to be an essential tool for the assessment effectiveness of existing policies/regulations, and it can be used to assess the impacts of other existing regulations (for example, regulation on decommissioning of nuclear facilities).

The nuclear liability system can be regarded as an important component in the nuclear legislative framework, which aims to ensure the adequate compensation of the public in case of a nuclear accident, whilst ensuring the viability of the nuclear industry.

\section{Acknowledgements}

We are very grateful to experts for their appropriate and constructive suggestions to improve this template.

I wish to extend my gratitude to the following people and institutions that contributed to the success of the study:

- My research supervisor, Mr MJ Mabiza for his guidance and valuable time.

- The National Nuclear Regulator (NNR) experts who participated in the Study: Ms Kgomo, Mr Pather, Mr Bester, providing in-depth knowledge about the subject and the NNR.

- My mentors, Ms Kgomo, Mr Nhlapho, and Mr Maphoto.

\section{REFERENCES}

[1] Heffron R.J., Ashley S.F, Nuttall W.J, "The Global Nuclear Liability Regime Post Fukushima Daiichi," Progress in Nuclear Energy, vol. 90, pp. $1-10,2016$. DOI: 10.1016/j.pnucene.2016.02.019

[2] Qasaymeh K.A., "South Africa's Peaceful Use of Nuclear Energy Under the Nuclear Non-Proliferation Treaty and Related Treaties", University of South Africa, http://uir.unisa.ac.za/bitstream/handle/10500/13855/thesis_ qasaymeh_ka.pdf?sequence $=1$ \&isAllowed=y $\quad$ (accessed June. 12, 2017).

[3] Zeidan S.M.M., "State Responsibility and Liability for Environmental Damage Caused by Nuclear Accidents", Tilburg University, https://research.tilburguniversity.edu/e $\mathrm{n} /$ publications/state-responsibility-and-liability-for-environ mental-damage-cause (accessed June. 20, 2017).

[4] Shah H.N., Rallapali R., "Fukushima Daiichi - 2011: Nuclear disaster: Lessons learned: Where we stand in India," International Journal of Health System and Disaster Management, vol. 1, no. 3, pp. 135 - 142, 2014. DOI: 10.4103/2347-9019.129136

[5] Pelzer N., "Facing the challenge of nuclear mass tort processing," Nuclear Law Bulletin, vol. 99, no. 1, pp. 45 69, 2017. DOI: 10.1787/nuclear_law-2017-5j8jpsxxxjwk. 
[6] Dechezleprêtre A., Sato M., "The impacts of environmental regulations on competitiveness," Review of Environmental Economics and Policy, vol. 11, no. 2, pp. 183 - 206, 2017. DOI: $10.1093 /$ reep/rex013

[7] Weitzdörfer J., "Week 1: Nuclear Power, Regulatory Capture, and the Case of Fukushima", Darwin College Cambridge, https://www.law.cam.ac.uk/sites/www.law.ca m.ac.uk/files/images/www.law.cam.ac.uk/documents/camb ridge_fukushima_schedule.pdf (accessed August 24, 2017).

[8] OECD., "Progress towards a Global Nuclear Liability Regime," Nuclear Law Bulletin, vol. 93, pp. 9 - 24, 2014. DOI: $10.1787 / 16097378$

[9] Iftime E., "Liability for Damage Caused by Dangerous Situations and Activities to the Environment," Procedia Social and Behavioral Sciences, vol. 149, pp. 417 - 423, 2014. DOI: $10.1016 /$ j.sbspro.2014.08.200

[10] Fork W.E., Peterson C.H., "Fusion energy and nuclear liability considerations," Nuclear Law Bulletin, vol. 93, pp. 43 -61, 2014. DOI: 10.1787/nuclear_law-2014-5jrtpsj53f $7 \mathrm{~h}$

[11] Davies D.B., "The Convention on Supplementary Compensation for Nuclear Damage and participation by developing countries: A South African perspective," Nuclear Law Bulletin, vol 93, pp. 25 - 42, 2014. DOI: 10.1787/nuclear_law-2014-5jrtpsj3tgg3

[12] Thomas A., Heffron R.J., "Third Party Nuclear Liability: The Case of a Supplier in the United Kingdom”, University of Cambridge, http://www.eprg.group.cam.ac.uk/wp-conte nt/uploads/2012/02/EPRG1205_complete_revised.pdf (accessed December 10, 2017)

[13] Mohan M.P.R., "Nuclear Energy and Liability in South Asia, Chapter 2: The Development of Institutions and Liability Laws Relating to Nuclear Energy", India: Springer Science and Business Media Company, http://www.spring er.com/cda/content/document/cda_downloaddocument/978 8132223429-c2.pdf?SGWID=0-0-45-1502815-p17729030 8 (accessed December 5, 2017)

[14] Marsden E., "Risk regulation, liability and insurance: Literature review of their influence on safety management", France: Foundation for an Industrial Safety Culture, https://www.foncsi.org/en/publications/collections/industri al-safety-cahiers/risk-regulation-liability-insurance/CSI-re gulation-liability-insurance.pdf. (accessed March 27, 2018)

[15] Feldman E.A., “Compensating the Victims of Japan's 3-11 Fukushima Disaster," Asian-Pacific Law \& Policy Journal, vol. 16, no. 2, pp. $127-157,2015$. DOI: 10.18488/journal.1.2019.912.752.764

[16] Shree A., "Nuclear Accidents: Estimates and Beyond", https://www.inflibnet.ac.in/ojs/index.php/JARPS/article/do wnload/3041/2347 (accessed 31 January 2018)

[17] Nuttall W.J., Ashley S.F., Heffron R.J., "Compensating for severe nuclear accidents: An expert elucidation," Process Safety and Environmental Protection, vol 112, pp. 131-142, 2017. DOI: 10.1016/j.psep.2016.12.008

[18] Rimšaitė L., "Civil Liability for Nuclear Damage: Comparative Analysis of International Treaties," Social Transformations in Contemporary Society, http://stics.mru ni.eu/wp-content/uploads/2013/06/16-23.pdf

(accessed August 7, 2017)

[19] Ampovska M., "Nuclear Insurance Pools Worldwide: The Role in the Nuclear Law," Balkan Social Science Review, vol. 9, pp. 7 - 21, 2017. DOI: 10.46763/BSSR

[20] Reichel L., Schmeiser H., "The Liability Regime of Insurance Pools and Its Impact on Pricing," North American Actuarial Journal, vol. 22, no. 4, pp. 1-21, 2015. DOI: $10.1080 / 10920277.2018 .1462717$

[21] Viscusi W.K., Gayer T., "Behavioral Public Choice: The Behavioral Paradox of Government Policy", Arlington: Mercatus Center at George Mason University, https://www.mercatus.org/system/files/Viscusi-Behavioral -Public-Choice.pdf (accessed March 27, 2018)

[22] Cooper J. C., Kovacic W. E., "Behavioral Economics: Implications for Regulatory Behavior," Journal of Regulatory Economics, vol. 41, pp. 41-58, 2016. DOI: 10.1007/s11149-011-9180-1

[23] Carrigan C., Coglianese C., "Capturing Regulatory Reality: Stigler's The Theory of Economic Regulation”, University of Pennsylvania Law School, http://scholarship.law.upenn. edu/faculty_scholarship/1650 (accessed March 27, 2018)

[24] Carpenter D., Moss D.A., "Preventing Regulatory Capture: Special Interest Influence and How to Limit it", in Preventing Regulatory Capture: Special Interest Influence and How to Limit it, NY: CUP, 2013, pp.381-384.

[25] Dhaliwal I., Tulloch C., "From Research to Policy: Using Evidence from Impact Evaluations to Inform Development Policy," Journal of Development Effectiveness, vol. 4, no. 4, pp. 515 - 536, 2012. DOI: 10.1080/19439342.2012.716857

[26] Pearce J.M., "Limitations of Nuclear Power as a Sustainable Energy Source," Sustainability, vol. 4, pp. 1173 - 1187, 2012 DOI: 10.3390/su4061173

[27] Huhtala A., Remes P., "Quantifying the social costs of nuclear energy: Perceived risk of accident at nuclear power plant," Energy Policy, vol 105, pp. 320 - 331, 2016. DOI: 10.1016/j.enpol.2017.02.052

[28] Roberts S., "Barriers to entry and implications for competition policy. Competition Commission and Tribunal 2016 Conference", University of Johannesburg, http://www.compcom.co.za/wp-content/uploads/2016/07/B TE_CompComConference2016_Roberts_draftsent.pdf (accessed April 16, 2018)

[29] Mchunu N. A., "The Link Between Poor Public Participation and Protest: The Case of Khayelitsha", Stellenbosch University, http://hdl.handle.net/10019.1/716 75

[30] Michael W., "Conflict of law issues related to Switzerland's participation in the Paris Nuclear Third Party Liability Regime," Nuclear Law Bulletin, vol 90, no. 2, pp. 31 - 69, 2013. DOI: 10.1787/nuclear_law-2012-5k480sc4fpvb

[31] Quéré A., "Challenges facing the insurance industry since the modernisation of the international nuclear third party liability regime," Nuclear Law Bulletin, vol 94, no. 2, pp. 77 - 94, 2015. DOI: 10.1787/nuclear_law-2014-5jrtpst439 wb

[32] Coglianese C., "Measuring Regulatory Performance: 
Evaluating the Impact of Regulation and Regulatory Policy", Organisation for Economic Co-Operation and Development, https://www.oecd.org/gov/regulatory-policy /1_coglianese\%20web.pdf (accessed December 5, 2017)
[33] NNR, "7th National Report, the Convention on Nuclear Safety - South Africa", National Nuclear Regulator, http://www.nnr.co.za/wp-content/uploads/2015/02/7th-CN S-Report-RSA.pdf (accessed: May 22, 2019). 